\title{
Global Shipping IPOs performance
}

\author{
ANDREAS MERIKAS* DIMITRIOS GOUNOPOULOS ${ }^{* *}$ and \\ CHRISTOS NOUNIS***
}

*Department of Shipping, University of Piraeus, Piraeus, 18532, Greece

**School of Management, University of Surrey, Guildford, Surrey, GU2 7XH, UK

${ }^{* * *}$ Department of Economics, University of Athens, Athens, 10559, Greece

\begin{abstract}
${ }^{1}$ We analyze the short and long-run price performance of 143 Global Shipping IPOs listed during the 1984-2007 period in major Stock Exchanges computing Buy \& Hold Abnormal Returns (BHAR) and Cumulative Abnormal Returns (CAR). We find average underpricing for shipping IPOs is $17.69 \%$. The light underpricing is positively related to the age of the firm, the reputation of the stock exchange they reach listing and the market condition of the period they go public and negatively related to the reputation of the underwriters. In the long-run, Shipping IPOs underperform after five months holding period. Specifically using the buy-and hold returns as a benchmark for long-run performance, we reveal that investors who buy immediately after listing and hold shares for three years will make a loss of $15.72 \%$. The survey suggests that Global Shipping industry surprises us regarding the maturity in the behavior of its investors.
\end{abstract}

\section{Introduction}

As shipping companies adjust to a dynamic and rapidly changing environment, so do the financial methods and instruments available to raise funding and materialize vital investment budgets. The core business strategy of shipping companies in recent days is gradually shifting from simple profit maximization to an increase in firm market value, Syriopoulos [1]. To achieve this, shipping firms should consistently focus on promoting investment plans that bear growth potential and have positive returns that outperform more than required costs undertaken. Two broad approaches can be distinguished in shipping capital financing: (i) self-sustained (internal) financing and (ii) external financing. In the second financing approach, the company turns to the international capital markets to raise the required investment funds. Capital markets play a key role in the promotion of shipping business growth and value creation. They act as intermediaries to provide the funds required to financing new investment projects and sustain business growth. Fresh funds are channelled to shipping firms in need through the issuance of securities. This issuance when it happens for first time is called as Initial Public Offering (IPO).

This paper investigates the underpricing and long-term performance of initial public offerings (IPOs) of common stocks in Global Shipping Industry (GSI). The purpose of this study is to provide a first piece of evidence regarding this sector with the so many unique characteristics $^{2}$. We would like to investigate how the underpricing of Shipping IPOs is affected

\footnotetext{
${ }^{1}$ To whom correspondence should be addressed. email:d.gounopoulos@surrey.ac.uk

${ }^{2}$ Shipping IPOs are distinct from those of ordinary industrial or service companies. The market value of a shipping company is often closely associated to the underlying value of the physical assets (vessels). In this respect, shipping IPOs bear similarities with the respective IPOs of closed end funds and property companies. Furthermore, due to extensive information flows in international vessel sales and purchase markets, shipping IPOs tend to exhibit lower information asymmetry. Due to the cyclical nature of shipping business, shipping companies tend to prefer equity markets when shipping market prospects appear to be promising
} 
by some institutional factors. In addition, we want to examine whether the long-term IPO underperformance documented in the United States and other developed markets also applies in a sector which bridges the people and contributes in the communication of the nations.

Many different theories, such as information asymmetry and signaling models, have been offered to explain the IPO underpricing phenomenon, Allen and Faulhaber [2]; Grinblatt and Hwang [3]; Welch [4]; Chemmanur [5]. IPOs underpricing - the phenomenon of a large positive gain to a new issue (relative to its offering price) immediately after listing - has been found in many markets. Loughran et. al. [6] document evidence of IPO underpricing in 25 countries, with higher figures in emerging than in developed markets. Compared with vast literature on individual country studies, the magnitude of studies on individual sectors is limited and specifically global shipping industry has been explored in the past only by Grammenos and Marcoulis [7] with a very small sample of 31 IPOs.

On early long run return evidences for IPOs, Ritter [8] and Loughran and Ritter [9] found that IPOs in the US underperform significantly relative to non-issuing firms for 3 to 5 years after the listing date. Many studies also provide international evidence on the long run underperformance of IPOs that is consistent with what has been observed in the US market as, Lee et al [10] in Australia, Cai and Wei [11] in Japan, Brounen and Eichholtz [12] in Sweden, Jaskiewicz [13] in Germany, Khurshed et. al. [14] in the United Kingdom, Chahine [6] in France, and Thomadakis et. at. [6] in Greece. In a pan-European study underperformance is documented by Gajeski and Gresse [15] for a sample covering 15 countries. They refer that long-term abnormal returns in Europe are negative.

The aim of the present study is to analyze various performance features of Shipping IPOs and to test if theories can adequately explain their behavior in the aftermarket. The study employs the buy-and-hold returns (BHARs) of the IPOs for 6, up to 36 months of listing in the market, the cumulative average returns (CARs) on a three-year basis to better test the stability and the Fama and French [16] three factor model. We find that using the BHAR and CAR benchmarks, there is significant overperformance in the first 5 months. Over the next months and up to $36^{\text {th }}$, there is underperformance which is confirmed as well across all benchmarks used. We therefore identify reducing over-performance as we are moving towards to six months after listing and underperformance as a robust feature over the last $2 \frac{1}{2}$ years we explore.

This study mainly makes four contributions to the international literature. First, it provides the first global evidence on the performance of IPOs in this crucial for many countries sector. The results show that Shipping IPOs underperform in long term, a finding that is consistent with Ritter's (1991) study for the US which underlines the fact that new listings significantly underperform even six months subsequent to listing. Second, this study investigates possible explanations for the short and long-run performance of the Shipping IPOs by using various factors concerning the global shipping environment market.

Third, we move on a comparative study as shipping firms of our sample have been listed in more than 10 different stock exchanges. We search among two options i.e. to list in one of the leading stock exchanges or to list in the local stock markets (country of shipping IPOs originality). Fourth the results indicate negative relationship between long-term IPO returns and initial underpricing. In particular, we find that new listings in shipping industry takes higher prices at the end of the first aftermarket day but the prices becomes lower than the offer price values in the long-run. The possible interpretation of this outcome is that the offering price set by issuers and underwriters is not very underpriced and reflects the firm's underlying fundamental value. This finding makes more difficult the answer to the question of why some offerings have extremely substantial initial returns and following positive post-listing returns when these IPOs afford no underpriced listing prices. 
The remainder of the paper is organized as follows. Section 2 reviews the literature regarding the short and long term performance on countries with strong shipping background, while there is a review on the rationale behind the decision of shipping firms to go public. Data and methodology are presented in Section 3, whereas Sections 4 and 5 provides the empirical findings. Section 6 summarizes the main results and concludes the paper by offering further recommendations for future research. Finally, Appendixes A \& B provide details on the Leading Global Shipping IPO Stocks by Market Capitalization and on Stock Price of Selected Shipping Companies since IPO in the U.S.

\section{Background}

The initial return of an IPO relates the difference between the equilibrium price following the issue and the IPO price. The post-IPO equilibrium price is the first trade price following the IPO, or the first closing price, or a closing price observed a few days after the IPO date, Ritter [17]. The IPO price, by definition, is the price at which the new shareholders buy the shares at issue. It is jointly decided by the underwriter and the listing firm at the end of the IPO procedure according to financial analysts' valuations and the demand expressed for the shares, The definitive offer price is generally lower than the first equilibrium price, which is well known under the term of IPO underpricing, Ljungqvist [18]. This part of our work is devoted to providing an overview of IPO performance in Global Shipping Industry. The following subsection documents initial returns and long-run performance in various strongly shipping related countries.

\subsection{Performance of IPOs in strongly Shipping Countries}

Loughran et. al. [19] in their updated global study on the level of underpricing report initial returns for a sample of 15,490 US IPOs of $18 \%$. On the long-term performance field and in a sample of 1,526 US IPOs, (issued between 1975-1984), Ritter [8] found that they underperformed their market benchmarks by about $-34.47 \%$ in the three year period, whereas Ritter and Welch [20] indicate that three-year holding-period returns for an investor, buying at the offer price, would on average underperform the market significantly.

In the UK as can been seen in Table 1, Champers and Dimson [21] and Gajeski \& Gresse [15] investigated short and long-term performance of a sample of 1,987 and 306 IPOs respectively issued during 1987-2007 for the short term and 1995-2004 for the long term. Champers and Dimson [21] report that British IPOs are underpriced by $19.0 \%$ and Gajeski \& Gresse [15] indicate that they offer negative returns in a three-year period by $-27.74 \%$. Furthermore, a study of Danish IPOs, concluded that the market performed better than the IPO stocks and the volatility adjusted under performance of the IPOs, compared to the market, was $30.4 \%$ after five years, while the level of underpricing has been only $8.1 \%$, one of the lowest percentages globally. Surprisingly though, IPOs in Sweden were found to have a long-run over performance, rather than negative long-term returns. Brounen and Eichholz [12] found a positive over-performance equal to $18.89 \%$. The short term performance of Swedish IPOs based on a sample of 406 firms is $27.3 \%$.

Consistent with previous studies, the mean raw return for the 2,104 European IPOs composing Gajeski and Gresse [15] sample on their first day of trading is very positive and equals $22.06 \%$. They calculate raw returns in logarithmic terms according to 4 different post-issue prices: the first closing price following the IPO, the closing price on the $5^{\text {th }}$ trading day following the IPO, the closing price on the 10th trading day following the IPO and the closing price one month after the issue. The average 1 st trading day adjusted return rises to $22.01 \%$, a value that is not significantly different from the average raw return of $22.06 \%$. These abnormal returns do not 
disappear in the short run and even grow slightly until the end of the first month of listing in most cases. Gajeski and Gresse [15] report on a sample of smaller sample of 1,846 IPOs when measuring 3-year performance that the long-term abnormal returns are frequently negative, but vary over time and across countries. They find a significant three-year underperformance with each measure: $-32.61 \%$ for BHAR, and $-87.19 \%$ for CAR.

Table 1. Global Evidence on Short and Long term performance of IPOs

\begin{tabular}{cccccc}
\hline Country & Researcher & Sample & Time Period & $\begin{array}{c}\text { Average Initial Average 3 year } \\
\text { Return }\end{array}$ & $\begin{array}{c}\text { Avong term } \\
\text { Size }\end{array}$ \\
\hline Australia & Lee et al. [10] & 266 & $1976-1989$ & $19.8 \%$ & $-51.25 \%$ \\
China & Chan et al [22] & 570 & $1993-1998$ & $164.5 \%$ & $75.07 \%$ \\
Denmark & Jakobsen and Sorensen [23] & 76 & $1984-1992$ & $8.1 \%$ & $-30.4 \%$ \\
Italy & Arosio et al [24] & 108 & $1985-1997$ & $18.2 \%$ & $-11.53 \%$ \\
Finland & Keloharju [25] & 79 & $1984-1989$ & $17.2 \%$ & $-21 \%$ \\
France & Chahine [6] & 172 & $1996-1998$ & $10.7 \%$ & $-9.4 \%$ \\
Germany & Stehle et al [26] & 187 & $1960-1992$ & $26.9 \%$ & $-6 \%$ \\
Greece & Thomadakis et al [27] & 254 & $1994-2002$ & $38.94 \%$ & $-15.35 \%$ \\
Sweden & Loughran et al [19] & 162 & $1980-1990$ & $27.3 \%$ & $1.2 \%$ \\
UK & Gajeski and Gresse [15] & 306 & $1995-2004$ & & $-27.74 \%$ \\
& Champers and Dimson [21] & 1987 & $1987-2007$ & $19 \%$ & \\
US & Ritter [8] & 1,526 & $1975-1994$ & $18 \%$ & $-34.47 \%$ \\
& Aggarwal and Rivoli [28] & 1,598 & $1977-1987$ & & -13.73 \\
Europe & Gajeski and Gresse (2006) & 1,846 & $1988-1998$ & & $-32.61 \%$ \\
\hline
\end{tabular}

Statistics on these initial and long term returns are reported in Table 1 for each country strongly related with Shipping Sector. The key role of equity markets on shipping business has been surprisingly neglected in past empirical research. An exception is Grammenos and Marcoulis [7], who studied shipping IPOs in a cross-country framework. A sample of 31 IPO cases was examined in seven different countries (US, Norway, Sweden, Greece, Luxembourg, Hong Kong and Singapore), over 1983-1995. Gearing was indicated to be the single most statistically significant factor in explaining IPO stock market performance. Furthermore, the average initial day return of Shipping IPOs was found to be $5.32 \%$. IPO costs were estimated at $8 \%$ of the amount raised with a high-fixed cost component in average direct costs. The highest direct costs were in the US stock markets and the lowest in Norway.

\subsection{Shipping companies going public}

Investment decisions in the shipping industry constitute a significant element of business uncertainty, since varying and persistent volatility is apparent between different shipping market segments. This is due to based a number of critical factors, including mainly the derived nature of demand for shipping services that is sensitive to economic growth, the cyclicality in freight rates and vessel prices, and the idiosyncratic sectoral characteristics of the shipping industry McGroarty [29]. Intensive capital resources tied-up in the underlying real assets (vessels) and

\footnotetext{
${ }^{3}$ Evidence from short term performance is from Loughran et al (1994) updated in 2008.
} 
can induce tremendous financial risk that, at times, may lead to adverse outcomes. As a consequence, financing tools shipping companies employ are in the core of shipping business.

Capital markets play a key role in the promotion of shipping business growth and value creation by performing the following fundamental functions. As primary markets, capital markets act as intermediaries to provide the funds required to financing new investment projects and sustain business growth. Fresh funds are channeled to firms in need through the issuance of securities. Furthermore, as secondary markets, capital markets provide an efficient mechanism for trading outstanding securities. They contribute, thus, to potential value creation that is reflected on corporate security prices.

As the business environment changes dynamically in the shipping industry, shipping companies turn to new financial instruments and markets (mainly to US) to finance their investment plans. A gradual shift is apparent in shipping finance more recently, driven by economic recessions and crises in the world markets. This move has been reinforced by the interactive impact of a number of factors as erosion of the capital reserves in many shipping companies, substantial contraction of banking finance, substantial capital requirements to replace the ageing wet and dry fleets worldwide, internationalization and integration of world capital markets and structural and cultural reorganization of shipping companies, induced by capital markets requirements and investors' expectations, Syriopoulos [30].

Despite their central role in investment funding, stock markets had traditionally only limited participation in shipping finance. Close family ownership ties, reluctance of shipowners to dilute company control, nondisclosure of sensitive company information and unattractiveness of shipping stocks to institutional and private investors, due to volatile cash flows, have been major reasons for that, Grammenos and Marcoulis [7].

Only recently shipping companies have discovered the virtues of public listing on international stock exchanges. The Shipping IPO wave of period 2000-2007 has tackled investors' appetite, as the latter rediscover the attractiveness of exchange traded shipping companies. This trend has been supported by unprecedented high-freight rates and strong shipping company balance sheets in an environment of bullish stock markets. Steady growth rates in the US economy and high-growth rates in the Chinese economy over the period 20032007 led the shipping sector to a peak in late 2007, generating strong earnings cash flows for shipping companies.

A fundamental problem for shipping companies interested in raising equity in the stock market is the pricing of the new issues. Since the majority of shipping IPOs refer to bulk shipping offerings, the issuer will set an IPO price at or near market-adjusted net asset value (NAV) per share. This is reasonable in cases where company earnings and cash flows fully support NAV, Stokes [31]. In practice, however, ship prices in the second-hand market do not necessarily reflect operating cash flow and earnings generated by the ships. More frequently, ship prices represent a very high multiple of operating cash flow, whereas in certain bulk shipping segments operating earnings have been negative for a number of years ${ }^{4}$.

\footnotetext{
${ }^{4}$ Stokes (1997) assumes that a shipping company can borrow at a spread over Libor (+1\% to $2 \%$ ), this can result to borrowing costs on senior debt of $7 \%$. Subordinate debt might cost 10-12\% per annum, on a 10-year maturity. Investors, however, will typically seek a return on equity of 15-20\% per annum, given the volatile freight markets and their risk exposure. This implies that most shipping companies, rated below investment grade, must attain return on equity well above average stock market returns in order to prevent their share price declining.
} 


\section{Data and Methodology}

A sample of 143 Global Shipping IPOs, was obtained for the period 1984-2007. Basic sources for the construction of the IPO database were the Annual Statistical Bulletins of the Stock Exchanges and the Prospectuses of companies. Data on long term total returns including both capital gains and dividend payments were computed from monthly returns data collected from DataStream and Bloomberg. Similarly, the returns on the indexes are measured as total returns including dividends. Share prices and prices of the General S.E. Index are collected at predetermined time points during the first three years of stocks' trading in the market. Appendix B provides a list of Selected Shipping Companies since IPO in the U.S. including their offer prices and prices in the end of the first day of trading.

A breakdown of these new listings per country, per stock market and per period is found in Table 2. New York S.E. and Nasdaq experienced the largest number of intakes. In particular, during the period we cover the common stocks of 55 new companies were listed in those two leading Stock Markets. It follows Oslo S.E. with 15 entries while London S.E. has only 6 listings. Surprisingly it is not US with the majority of Global Listed Shipping firms but Greece with 29 IPOs. Despite the big number of Greek entries only 6 of those were listed in the local Athens Stock Exchange. Opposite is the trend for Norway IPOs as all the fifteen Norwegian firms were listed in Oslo. In support to our view 'only recently shipping companies have discovered the virtues of public listing' there have been only 38 firms listed before the millennium. The rest were listed after 2000 and especially in Norway 14 out of 15 IPOs were listed in the end of the covered period. We should point out that the distribution of IPOs takes into consideration the entrance day of common stocks in the stock markets and not according to the public offering time period.

Table 2. Number of Shipping issues listed in global stock markets by year and by market: Time period: $1 / 1 / 1984-31 / 12 / 2007$

\begin{tabular}{cccccc}
\hline $\begin{array}{c}\text { Country of } \\
\text { Domicile }\end{array}$ & $\begin{array}{c}\text { Number of } \\
\text { Issues }\end{array}$ & $\begin{array}{c}\text { Market of } \\
\text { Listing }\end{array}$ & Number of Issues & $\begin{array}{c}\text { Listed before } \\
2000\end{array}$ & $\begin{array}{c}\text { Listed after } \\
2000\end{array}$ \\
\hline Belgium & 3 & Brussels S.E. & 2 & 0 & 2 \\
Bermuda & 7 & OTC & 4 & 2 & 2 \\
China & 5 & Shanghai S.E. & 1 & 0 & 1 \\
Denmark & 6 & Copenhagen S.E. & 5 & 1 & 4 \\
Finland & 4 & Helsinki S.E. & 3 & 2 & 1 \\
Germany & 3 & Berlin S.E. & 4 & 1 & 3 \\
Greece & 29 & Athens S.E & 6 & 5 & 1 \\
Hong Kong & 4 & Hong Kong S.E. & 5 & 0 & 5 \\
India & 6 & Bombay S.E. & 6 & 1 & 5 \\
Norway & 15 & Oslo S.E. & 15 & 1 & 14 \\
Singapore & 6 & Singapore S.E. & 7 & 4 & 3 \\
Sweden & 5 & Stockholm S.E. & 6 & 3 & 2 \\
UK & 4 & London S.E. & 6 & 1 & 5 \\
USA & 27 & NYSE & 30 & 9 & 21 \\
& & NASDAQ & 25 & 3 & 22 \\
Other & 19 & Other S.Es & 18 & 5 & 14 \\
TOTAL & $\mathbf{1 4 3}$ & & $\mathbf{1 4 3}$ & $\mathbf{3 8}$ & $\mathbf{1 0 5}$ \\
\hline
\end{tabular}




\subsection{Methodology}

Some authors (Brav et. al. [32]; Drobetz et. al. [33]; Álvarez and González, [34]) show that measured performance strongly depends on the selected methodology. We first analyse both initial returns and aftermarket returns. Then cross-sectional analyses are employed in an attempt to explore factors determining IPO performance. Finally, regression analyses are undertaken.

Coming to Shipping IPOs the underpricing of an issue is calculated as the return on the first day of trading relative to the offering price.

$$
\operatorname{Re} t_{0}=\frac{1}{n} \sum_{i=1}^{n}\left(\frac{P_{i 0}}{P_{I 1}}-1\right)
$$

Where Ret $_{0}$ is the average return (underpricing) of the IPO on the first trading day (day 0 ), $\mathrm{P}_{\mathrm{i} 0}$ is the closing price of stock $i$ on day 0 , and $P_{i t}$ is the offering price of stock $i$. We also adjust the return for the market effect:

$$
\text { Adjret }=\frac{1}{n} \sum_{i=1}^{n}\left(\frac{P_{i 0}}{P_{i 1}}-\frac{P_{i, m 0}}{P_{i, m 1}}\right)
$$

Where AdjRet ${ }_{0}$ is the average of the market adjusted returns (including dividends) of IPOs on day $0, \mathrm{P}_{\mathrm{i}, \mathrm{m} 0}$ is the closing value of the corresponding stock exchanges market index on the first trading day of the new issue $i, \mathrm{P}_{\mathrm{i}, \mathrm{ml}}$ is the closing value of the corresponding stock exchange market index on the offering day of the new issue $i$.

In order to gain further understanding we analyze share returns in the three year subsequent to listing. 'Fads' or 'speculative bubble' explanations of initial underpricing suggest a link between initial returns and post listing performance, as do those explanations in which underpricing is modeled as a signal for future performance. However, the direction of the relationship between initial and subsequent performance differs between these two approaches, so that analysis of 'long run' returns represents an important input into a thorough analysis of underpricing.

For the purposes of the study, the measure of the buy-and-hold returns (BHARs) will be used so as to evaluate the long-run performance of the Global Shipping IPOs. This methodology involves the calculation of the three years buy-and-hold returns assuming that the stocks are held from their public offering period or from the first trading day after their listing, to the threeyear anniversary of their listings.

The measurement of long-term performance is a complex matter. Three categories of measures are commonly implemented in the literature: buy-and-hold abnormal returns, cumulated abnormal returns and constant terms from multi-factor models. All closing stock prices are adjusted for share capital increases and stock splits that possibly happened during the three-year period ${ }^{5}$.

The adjusted return for issue $i$ is defined as the raw return less the corresponding market return for the same time period used for raw return calculation:

$$
\operatorname{ar}_{i t}=r_{i t}-r_{m t}
$$

\footnotetext{
${ }^{5}$ These calculations are appropriate because the equilibrium prices of stocks in the stock exchange reflect not only the special characteristics of each company but they also embody, at the process of their shaping, the ascending or descending trends of the stock market. So, the adjusted returns must be calculated, especially when the returns under consideration refer to a longer period, as it happens with the returns of this study.
} 
where $r_{i t}$ is monthly raw return for IPO in month $t ; r_{m t}$ is monthly market return in month $t$.

The average benchmark adjusted return on a portfolio of $\mathrm{n}$ stocks for event month $t, \mathrm{AR}_{\mathrm{t}}$, is the equally weighted and value weighted arithmetic mean of the benchmark adjusted returns.

$$
A R_{t}=\frac{1}{n} \sum_{i=1}^{n} a r_{i t}
$$

The CAR from event month $q$ to event month $s$ is calculated by cumulating the mean benchmark-adjusted returns over various intervals during the 36-month aftermarket period, $q$ to $s$, as follows

$$
C A R_{q, s}=\sum_{t=q}^{s} A R_{t}
$$

These $C A R$ s exclude the initial return by treating the return index on the first day of listing as a purchase price. The cumulative mean benchmark-adjusted return for months 1 to $36, C A R_{1,36}$ thus involves monthly rebalancing to achieve equal weighting each month, Ritter [8]).

The average benchmark-adjusted cumulative return of IPOs following introduction is the arithmetic equally-weighted mean of individual cumulative abnormal returns

$$
C A R=\frac{1}{n} \sum_{i=1}^{n} C A R_{i}
$$

The calculation of the aftermarket return does not fully take the effect of different risk levels into account ${ }^{6}$. The average market adjusted returns $\left(A R_{t}\right)$ and the cumulative abnormal return $(C A R s)$ for each month are tested for their significance.

To test the null hypothesis that the mean buy-and-hold abnormal return is equal to zero for the sample of IPO firms, we employ a conventional t-statistic. The $t$ statistics for the $\mathrm{AR}_{\mathrm{t}}$ series are calculated as:

$$
t\left(A R_{t}\right)=A R_{t} \frac{\left(n_{t}\right)^{1 / 2}}{s d_{i}}
$$

Abnormal returns are strongly dependent on the benchmark used. Previous studies suggest that the measure of long-run performance for IPOs is sensitive to the benchmark used. Barber and Lyon [35] show that when long-run, buy-and-hold abnormal returns are calculated using a reference portfolio, the test statistics are negatively biased. This bias is, however, not present when abnormal returns are calculated as the return of a sample firm less the return of a single control firm matched on size or book/market ratio. Furthermore, Brav and Gompers [36] have shown empirically that when controlling for size or book to market ratio effects, the longterm underperformance of IPOs decreases, or even disappears. In support to previous evidence

\footnotetext{
${ }^{6}$ It is assumed that IPOs have the same systematic risk as the market benchmark employed in the test, but it does not alter the direction of the results. Balvers et al. (1993) have documented that the systematic risk of new issues is greater than one which is the systematic risk of the market index. The assumption that IPOs have the same systematic risk as the market index, therefore, provides an upward bias in the estimation of the returns and strengthens the results (Ritter, 1991, and Aggarwal and Rivoli (1990).
} 
we make use of Fama and French [16] three Factors model (to calculate the abnormal return $\varepsilon_{\mathrm{i}}$ ), a multi-factor model in which stock or portfolio returns are regressed on a fixed number of common factors, the first factor being invariably the market return and the intercept representing the mean abnormal performance.

$$
\left(R_{p t}-R_{f t}\right)=a+\beta\left[\left(R_{m t}-R_{f t}\right)+\gamma S M B_{t}+\delta H M L_{t}+\varepsilon_{p t}\right.
$$

where $R_{p t}$ is the IPO portfolio return in month $t$, is the one-month U.S. Base Lending Rate, observed at the beginning of the month, $R_{f t}$ is the treasury bill (T-bill) return in event month $t$ and $R_{m t}$ is the monthly market return of the every associated ${ }^{7}$ Stock Exchange Composite Index ${ }^{8}$.

The next step involves the implementation of multivariate regression, in order to check for explanation of cross-sectional differences of the long-run performance of the IPOs. We have identified a number of potential determinants for the short and long-term underperformance of the IPOs, however for the purposes of a study on the shipping industry, six of them were selected and their significance levels are going to be examined. Therefore, the regression model is specified as follows:

$$
\mathrm{P}_{\mathrm{t}}=\mathrm{a}+\beta_{1} \log (1+\mathrm{AGE})+\beta_{2}(\mathrm{MRK})+\beta_{3}(\mathrm{UND})+\beta_{4} \log (\mathrm{SIZE})+\beta_{5}(\mathrm{H} / \mathrm{C})+\beta_{6}(\mathrm{EXC})+\varepsilon_{\mathrm{i}}(9)
$$

Where 'AGE', is the age of the issuing firm calculated as the number of years that each listing firm is in operation since its constitution before the year of listing, 'MRK' is the market where the Global Shipping IPOs has been classified (We insert the value '1' if an IPO listed in Main Market, and ' 0 ' if listed in Secondary/Parallel/New Market). UND is the Underwriters reputation getting ' 1 ' for reputable underwriters ${ }^{9}$ and ' 0 ' for non reputable. 'SIZE' is the logarithm of the market capitalisation of an IPO, H/C describes the period of listing: IPOs listed in the Hot Period get the value of ' 1 ' and IPOs listed in Cold Period get the value ' 0 ' and finally 'EXC' is the reputation of the stock exchange Shipping IPOs are listed, ' 1 ' for reputable stock exchanges (NYSE, NASDAQ and LSE) and ' 0 ' for non reputable.

\section{Aftermarket performance}

\subsection{Determinants of Shipping IPOs underpricing}

We will include several variables to explain cross-sectional variations of underpricing. The first variable is the history of a firm prior to going public, (AGE). Unlike in technology sector where the great majority of the firms have short history, it is typical in shipping industry, the new issues to be offered for public subscription with more than ten years history before their listing on the stock exchanges. Due to the asymmetric information distribution among the issuer, underwriters and investors (Baron [37]; Rock [38]) and to the fact that funds will be tied up, a

\footnotetext{
${ }^{7}$ It can be New York Stock Exchange, London Stock Exchange, NASDAQ etc

${ }^{8} S M B_{i}$ is the monthly return on the zero investment portfolio for the size factor in the stock returns, namely the difference between the equal-weight mean of the returns on a portfolio of small stocks and a portfolio of big stocks, constructed independently from the book-to-market value portfolio, and $H M L_{i}$ is the monthly return on the zero investment portfolio for the book-to-market equity factor in stock returns, namely the difference between the return on a portfolio of high book-to-market ratio stocks and the return on a portfolio of low book-to-market ratio stocks, constructed independently from the size portfolio.

${ }^{9}$ We consider as reputable underwriters the following five institutions: Citigroup, Goldman and Sachs, J.P Morgan, Merrill Lynch and UBS
} 
short history before going public will increase the risk to investors so that a larger underpricing is required. Therefore, we expect a negative relation between AGE and underpricing.

The second variable is the regulated market (MRK) in which the Shipping IPOs have been listed. In principle, on every stock exchange, a company has a choice between three regulated market segments in which to list its shares: the 'Main Market' designed for the listing of large companies, the 'Parallel Market' that caters to middle and small capitalisations and the 'New Market' for growing companies ${ }^{10}$. Firms that are listed mainly in the 'Parallel Market' and the 'New Market', will underprice their shares, because they need to attract a large number of small shareholders to create a broader ownership structure. However, being at a disadvantage in terms of the information they have at their disposal, small investors participate in an IPO if they are compensated for the adverse selection costs they incur, that is if the IPO is sufficiently underpriced, Gajeski and Gresse [15].

The third variable is the underwriters' reputation (UND) ${ }^{11}$. Typically, a banking syndicate or an investment bank, called 'the underwriter', is involved in developing the admission statement and is in charge of the flotation and underwriting process. The underwriter is chosen by the IPO candidate after a so-called 'beauty contest' at which banks or other financial institutions present their proposals for the IPO. Ruud [39] finds that underwriters stabilise stock prices during a short period of time after the IPO so as to avoid a failure of the issue. Prices are artificially supported at a high level in the short run, but at the end of the stabilisation period, performance decreases. According to Carter et al. [40], based on three measures of underwriter bank prestige, mean long-term underperformance of firms introduced by more prestigious underwriters is weaker. This result acts in favour of the hypothesis of underwriter reputation, according to which the selection of a highly ranked underwriter would be a good signal for the market with regard to the risk borne in the post-IPO period. Therefore, we expect a negative relation between UND and underpricing.

The fourth variable is the size of IPO measured as the natural logarithm of the total number of shares times the offer price, Log (SIZE). To determine if the price reaction to Shipping IPOs is affected by offer size, as shown by Chalk and Peavy [41] and Ibbotson et. al. [42] for U.S. IPOs, we dissect our sample into four size categories (Table 3). The literature (Brav and Gompers, 1997; Stehle et al., 2000; Schuster, 2002; Drobetz et al., 2005;) indicates that long-term performance is sensitive to size. Several authors, especially Brav and Gompers (1997), Stehle et al. [26], Brav et al. [32], argue that benchmarks built upon size give more reliable results.

\footnotetext{
${ }^{10}$ Some exchanges make exceptions to this rule. First, the Stockholm stock exchange (OMX, Sweden), the Vienna stock exchange (VSE, Austria) and the Warsaw stock exchange (WSE, Poland) never opened a New Market, and the Swiss exchange (SWX) and Deutsche Börse recently closed their New Markets. Second, the LSE and Euronext Amsterdam do not have a specific market segment for the listing of medium and small capitalisations since their Main Markets accept all firms, independent of size considerations, unless market capitalisation exceeds GBP 700,000 at the LSE and shareholders' equity is over EUR 5 millions on Euronext Amsterdam. At the LSE, the market segmentation between large, middle and small capitalisation stocks only applies to the secondary market, which is organized in different trading platforms according to liquidity and market recognition criteria

${ }^{11}$ Chemmanur and Fulghieri (1994) argue that investors use the investment bank's past performance, as measured by the quality of firms in which they have previously sold equity, to assess their credibility. Given these considerations, we ranked underwriters based on their market share and paid-in capital. We also employed a survey of brokers on the trading floor to check the quantitative ranking results used in previous studies. The underwriters' ranks place them in one of three categories, where one represents the most prestigious underwriter and three the least prestigious underwriter.
} 
The opportunities ${ }^{12}$ for an IPO may be determined by the fifth adopted variable, market conditions. Lowry [43] suggests that in a bullish market, the number of IPOs tends to increase because the placement of stocks is easier, the risk of failure of an IPO is lower and securities are priced higher, which softens the cost of initial underpricing. Most investors globally are not country specific, Ritter [44]. They look at one big Global market and its index. In that case IPOs made under hot market conditions, which represents heavy interest by investors in the IPO, are expected to yield larger returns in the first few trading days than IPOs made in a cold market. The prices of hot market IPOs reverse as a result of change in beliefs of investors who realize that too much optimism may be attributed to the new issues (overvaluation) under the hot market conditions after some time elapses following the IPO. This reversion in prices relative to the market generates underperformance of IPOs made in hot markets. Nonetheless since 2003, four of the largest Global markets - US, $\mathrm{UK}^{13}$, Germany and France have enjoyed a five year stock market rally and a bullish market for IPOs.

Buttimer et. al. [45] and Freybote et. al. [6] on their studies define a hot IPO market as a period during which at least ten IPOs are conducted per year. The number of IPOs per annum indicates that our twenty four-year observation period is characterized by four successive subperiods: a 'cold' period from 1984 to 1997, a 'hot' market in 1998-2000, an extremely 'cold' market from the end of 2000 to 2002 and an extremely 'hot' period from 2003 to end of 2007. From 2003 onwards, there have been at least 10 shipping IPOs per year so by definition this period can be regarded as hot IPO market. The average number of Shipping IPOs per year in our sample totaled 11.1 between 1998 and 2007. However, there have been approximately 3 Shipping IPOs per year between 1988 and 1997 and only 2 IPOs in total between 1984 and 1987. Hence it justified to classify the period 1998-2007 as a hot IPO market for shipping companies around the world. This hypothesis is further supported by practitioners such as Merrill Lynch [30] who refer to the Global Shipping market in 2005 as a bull market.

The sixth variable, 'EXC' is mainly determined by the reputation of the stock exchange where the IPOs are listed. We classify our sample in two big categories: shipping IPOs which are listed in the main global stock markets (NYSE, NASDAQ and LSE) and firms listed in all other stock exchanges. We hypothesize based on the more strict entrance standards which we meet in the mature markets that there is a negative relationship between Shipping IPOs listed in the main stock exchanges and the underpricing.

\subsection{Determinants of long run performance}

Following previous country studies, our long term return period covers the first, second and third year of trading, i.e., it relates the first, second and third closing year price to the end of the first day of trading price of an issue. We calculate benchmark-adjusted returns as the adjusted return on a stock minus the benchmark return over the first, second and third year of trading. We use daily returns on the total stock markets indexes provided by DataStream and Bloomberg as the benchmark. The underlying trading strategy is ex ante implementable and

\footnotetext{
12 According to the timing hypothesis, managers choose a window of opportunity to launch an IPO, this window being identified as a function of the firm's performance or market conditions. First, managers prefer to take their firms public when they have performed well earlier, and probably the IPO date is conditional on the firm's cycle of activity and operational performance. Second, the window of opportunity for an IPO may be determined by market conditions. In a bullish market, the number of IPOs tends to increase because the placement of stocks is easier, the risk of failure of an IPO is lower and securities are priced higher, which softens the cost of initial underpricing. Loughran and Ritter (1995) as well as Helwege and Liang (2001) show that firms going public during 'hot markets' have more severe long-term underperformance than other firms.

${ }^{13}$ The UK's IPO market has been robust, heavily weighted with jumbo listings in 2006. The UK's 151 deals were the fifth highest number of IPOs in the world in 2006 and raised US \$17.2 billion.
} 
follows a simple rule: Each IPO is bought at the end of first day of trading and sold at the end of first, second and third year of trading. Because there is no ex ante information about a specific weighting scheme, the long term returns are equally weighted, i.e., the same amount of money is invested in every IPO.

Panel A reports the distribution of two and three-year holding period returns for all the 143 Shipping IPOs and their matching firms. The median IPO 3-year return is -27.00\% contrasted with the positive $22.54 \%$ for the median matching firm. In line with Ritter (1991) the distribution of IPO 3-year holding period returns is more skewed than that of the matching firms.

Panel B segments IPOs by market capitalization during the offer price period. Appendix A helps us get an idea of the Leading Global Shipping IPOs categorized by Market Capitalization as it indicates that A.P. Moller from Denmark has been by far the largest with 32.67 billion dollars. A first glance in the numbers in Panel B show that there is a trend for larger offers to have better aftermarket performance in both 2-years and 3-years returns. Matching firms' adjusted long term returns do not drive to any secure findings as there is almost no fluctuation among the different periods of this study. If the sample will be segregated in four parts i.e. IPOs with market capitalization smaller than $\$ 200$ million (small IPOs), IPOs of capitalization between $\$ 200-400$ million (second) and \$400-600 million (third) and finally with IPOs having market capitalization larger than $€ 800$ million (large IPOs), the BHAR of the firms with small capitalization proves to be $-18.33 \%$ and $-15.56 \%$ for 2 - and 3-years while the BHAR for IPOs with large capitalization is $15.32 \%$ for two and $11.11 \%$ for three years. The result is consistent with what we expect to find and especially that IPOs issued by large firms, tend to perform better in the long-run, gaining higher and significant returns. Our results confirm Ritter (1991) evidence that, larger offers have better aftermarket performance.

Panel C, classifies IPOs based on their age at the time of going public. We find strong relation between age and long term performance as the more the years in shipping business the better the long term performance of an IPO. In line with Ritter (1991) we interpret the poor long run performance of the younger shipping IPOs, which typically face higher levels of risk. Comparison between 2 and three years after going public reveals that returns become weaker as the time moves on.

In panel $\mathrm{D}$, firms are categorized by the stock exchange of issuance. The results show that Shipping IPOs listed in the mature market of U.S experience low level of underpricing in the long term which is $13.85 \%$ for Nasdaq and only $5.55 \%$ for NYSE three years after going public. Less developed markets experience either high level of underpricing or overpricing. Specifically Shipping IPOs listed in Athens S.E. were underpriced by $47.50 \%$ while there are a number of countries which present overpricing on their Shipping IPOs as Bombay with $134.05 \%$, Oslo with $103.56 \%$ Stockholm with $-96.64 \%$ and Copenhagen with $93.15 \%$. 
Table 3. Distributional statistics for long run average market index adjusted returns and aftermarket performance categorized by Gross Proceeds, Age of the Issuing Firm and

\section{Year of going public}

Panel A: Three-year holding period returns are calculated as $\left[\Pi^{756}\left(1+\mathrm{r}_{\mathrm{idt}}\right)-1\right]^{* 100}$ where $\mathrm{r}_{\mathrm{idt}}$ is the daily return on stock $i$. For IPOs that were delisted before the 3-year anniversary, the total return is calculated until the delisting date. The corresponding matching firm's total return is calculated over the same truncated return interval. Panel B: Gross proceeds are measured in Euros of 2000 purchasing power using the official European Union exchange rate with Greek Drahmas, $€ 1=340.75 \mathrm{drh}$. Initial returns are computed as $r_{\text {ipo }} \mathrm{r}_{\text {matching firm }}$ over the initial return interval The three year holding period return is calculated excluding the initial return. Total return includes both capital gains and dividends. Panel C: The IPOs are categorized based on their age the year of going public.

Panel A: Distribution of three year holding period returns

\begin{tabular}{|c|c|c|c|c|c|}
\hline \multirow[b]{2}{*}{ Rank } & \multicolumn{2}{|c|}{ Two years holding period total return } & \multicolumn{3}{|c|}{ Three years holding period total return in percent } \\
\hline & $\begin{array}{l}\text { Initial Public } \\
\text { Offering }(\%)\end{array}$ & $\begin{array}{c}\text { Matching Firm } \\
(\%)\end{array}$ & $\begin{array}{c}\text { Initial Public } \\
\text { offering }(\%)\end{array}$ & $\begin{array}{c}\text { Matching Firm } \\
(\%)\end{array}$ & \\
\hline Minimum & -154.33 & -96.46 & -220.79 & -88.75 & \\
\hline $25^{\text {th }}$ percentile & -75.90 & -12.84 & -95.30 & -19.58 & \\
\hline Median & -10.41 & 31.93 & -27.00 & 22.54 & \\
\hline $75^{\text {th }}$ percentile & 48.36 & 76.32 & 37.99 & 61.49 & \\
\hline Maximum & 346.03 & 107.76 & 326.54 & 102.56 & \\
\hline \multicolumn{6}{|c|}{ Panel B: Aftermarket performance categorized by Market Capitalization } \\
\hline Market Cap \$ & & & & & Sample Size \\
\hline$<200$ mil & -18.33 & 41.27 & -15.56 & 48.34 & 36 \\
\hline $201 \mathrm{mil}-400 \mathrm{mil}$ & 0.90 & 46.13 & 0.79 & 49.65 & 37 \\
\hline $401 \mathrm{mil}-800 \mathrm{mil}$ & 2.64 & 40.49 & -3.96 & 45.18 & 35 \\
\hline$>800 \mathrm{mil}$ & 15.32 & 44.74 & 11.11 & 47.82 & 35 \\
\hline
\end{tabular}

Panel C: Aftermarket performance categorized by Age of the Issuing firm

\begin{tabular}{cccccc}
\hline Age in Year & \multicolumn{2}{c}{ Sample Size } \\
$0-5$ & -2.70 & 37.68 & -21.72 & 44.84 & 50 \\
$6-10$ & -14.54 & 40.52 & -26.58 & 51.26 & 31 \\
$21-50$ & 17.95 & 41.89 & 8.21 & 49.63 & 31 \\
$50-$ up & 22.07 & 43.12 & 10.29 & 55.17 & 31 \\
\hline \multicolumn{7}{r}{ Panel D: Aftermarket performance categorized by Stock Exchange of Listing } \\
\hline Stock Exchange & 6 months & 12 months & 24 months & 36 months & \\
Athens & 84.30 & 66.46 & 78.20 & 47.50 & 6 \\
Bombay & -93.81 & -97.73 & -116.86 & -134.05 & 6 \\
Copenhagen & -43.15 & -56.03 & -75.98 & -93.15 & 5 \\
NASDAQ & 7.97 & 16.96 & 28.79 & 13.85 & 25 \\
New York S.E, & 17.23 & 8.21 & 21.94 & 5.55 & 30 \\
Oslo S.E. & -93.74 & -98.63 & -99.29 & -103.56 & 15 \\
Singapore S.E & -33.98 & -3.24 & 18.88 & -16.05 & 7 \\
Stockholm S.E & -84.76 & -90.31 & -95.51 & -96.64 & 6 \\
Others & 0.89 & 2.60 & 8.16 & 5.10 & 43 \\
\hline
\end{tabular}


4.2. Summary Statistics for the Buy-And-Hold Abnormal Returns (BHARs) of IPOs.

Table 4 provides the average Buy-and-Hold Abnormal Returns (BHARs) of Global Shipping IPOs listed during the period 1984-2007. Panel A shows the adjusted returns that are calculated taking as a reference point the listing price of new issues and the closing price of the

Table 4. Buy-And-Hold Adjusted Returns for Global Shipping IPOs: Time Period 1984-2007

\begin{tabular}{lcccccc}
\hline \multicolumn{6}{c}{ Panel A: Excess or Adjusted Returns based on the listing price } \\
\hline Return of & $\begin{array}{c}\text { Mean Return } \\
(\%)\end{array}$ & $\begin{array}{c}\text { Standard } \\
\text { Deviation } \\
(\%)\end{array}$ & $\begin{array}{c}\text { Number of } \\
\text { observations }\end{array}$ & $\begin{array}{c}\text { Median } \\
(\%)\end{array}$ & $\begin{array}{c}\text { Minimum } \\
\text { Return } \\
(\%)\end{array}$ & $\begin{array}{c}\text { Maximum } \\
\text { Return } \\
(\%)\end{array}$ \\
\hline 1 st day & 17.69 & 32.01 & 143 & 8.69 & -25.56 & 201.45 \\
6 months & -13.52 & 68.74 & 143 & -6.74 & -139.60 & 215.38 \\
12 months & -9.91 & 81.76 & 141 & -16.86 & -139.02 & 311.78 \\
24 months & -4.40 & 95.55 & 134 & -15.76 & -154.13 & 343.85 \\
36 months & -15.72 & 104.48 & 127 & -27.85 & -220.79 & 309.78
\end{tabular}

Panel B: Excess or Adjusted Returns based on the first day closing price

\begin{tabular}{lcccccc}
\hline Return of & $\begin{array}{c}\text { Mean Return } \\
(\%)\end{array}$ & $\begin{array}{c}\text { Standard } \\
\text { Deviation } \\
(\%)\end{array}$ & $\begin{array}{c}\text { Number of } \\
\text { observations }\end{array}$ & $\begin{array}{c}\text { Median } \\
(\%)\end{array}$ & $\begin{array}{c}\text { Minimum } \\
\text { Return } \\
(\%)\end{array}$ & $\begin{array}{c}\text { Maximum } \\
\text { Return } \\
(\%)\end{array}$ \\
\hline 6 months & -23.56 & 57.91 & 143 & -17.51 & -136.65 & 270.57 \\
12 months & -21.12 & 67.93 & 142 & -25.18 & -144.30 & 288.32 \\
24 months & -18.05 & 87.03 & 134 & -25.13 & -159.86 & 241.50 \\
36 months & -29.17 & 87.69 & 127 & -41.96 & -228.96 & 281.26
\end{tabular}

Panel C: Excess or Adjusted Returns based on the first month closing price

\begin{tabular}{lcccccc}
\hline Return of & $\begin{array}{c}\text { Mean Return } \\
(\%)\end{array}$ & $\begin{array}{c}\text { Standard } \\
\text { Deviation } \\
(\%)\end{array}$ & $\begin{array}{c}\text { Number of } \\
\text { observations }\end{array}$ & $\begin{array}{c}\text { Median } \\
(\%)\end{array}$ & $\begin{array}{c}\text { Minimum } \\
\text { Return } \\
(\%)\end{array}$ & $\begin{array}{c}\text { Maximum } \\
\text { Return } \\
(\%)\end{array}$ \\
\hline 6 months & 2.09 & 35.84 & 143 & -2.19 & -113.28 & 133.32 \\
12 months & 8.25 & 55.73 & 142 & -3.22 & -105.40 & 248.49 \\
24 months & 18.93 & 72.29 & 134 & 5.05 & -135.23 & 245.04 \\
36 months & 9.77 & 83.34 & 127 & -7.34 & -204.94 & 228.30 \\
& & & & & & \\
\hline
\end{tabular}

Panel D: Excess or Adjusted Returns based on the six months closing price

\begin{tabular}{lcccccc}
\hline Return of & $\begin{array}{c}\text { Mean Return } \\
(\%)\end{array}$ & $\begin{array}{c}\text { Standard } \\
\text { Deviation } \\
(\%)\end{array}$ & $\begin{array}{c}\text { Number of } \\
\text { observations }\end{array}$ & $\begin{array}{c}\text { Median } \\
(\%)\end{array}$ & $\begin{array}{c}\text { Minimum } \\
\text { Return } \\
(\%)\end{array}$ & $\begin{array}{c}\text { Maximum } \\
\text { Return } \\
(\%)\end{array}$ \\
\hline 12 months & 5.18 & -48.36 & 141 & 1.74 & -48.36 & 179.96 \\
24 months & 17.00 & -109.62 & 134 & -2.76 & -109.62 & 250.70 \\
36 months & 5.83 & -173.82 & 127 & -7.09 & -173.82 & 238.56 \\
\hline
\end{tabular}

$* * *$ Significance level at $1 \%, * *$ Significance level at 5\%, *Significance level at $10 \%$ 
General Index of Each Stock Exchange (GIESE) on the last date of public offerings period. The second panel reports the BHAR that are calculated, taking as a reference point the closing price of new listings at the end of first day of their trading in the stock market and the closing price of GIESE at the same date while the third panel reports the adjusted returns considering as a reference point the end of first month of trading and the closing price of GIESE at the same date.

Table 4, Panel A, reveal initial excess returns of $17.69 \%$ which is considerably low comparing to many country studies, Loughran et. al.[6]. This low level of underpricing is a first proof that Shipping Industry is mature and both underwriters and shipping issuers are doing very well their job. Moreover, the one year mean adjusted return that calculated according to the listing price, the first day closing price, and the first month closing price was $-9.91 \%,-21.12 \%$ and $9.25 \%$ respectively and the corresponding three-year return was $-15.72 \%,-29.17 \%$ and 9.77\%. These results indicate that new Shipping issues in global environment offer to investors' negative returns if the investment will take place during the offer price period or the end of the first trading day while returns turns to be positive if someone will invest in the end of the first month and thereafter.

In other words, we find evidence that investors who participated in the Global Shipping IPO, buying stocks at the listing price or at the closing first day price and holding them for a three-year period, obtained short negative returns because the listing prices of IPOs were slightly higher than their equilibrium prices formed at the $750^{\text {th }}$ day of trading. It is also notable that the range of the above IPO returns is wide, fluctuating from $-220.79 \%$ to $309.78 \%$ (adjusted returns based on listing price) from $-228.96 \%$ to $281.26 \%$ (adjusted returns based on first day closing price) and from $-204.94 \%$ to $228.30 \%$ (adjusted returns based on first month closing price).

Table 5 reports the average matching firm adjusted returns $\left(A R_{t}\right)$ and cumulative average matching firm adjusted returns $\left(\mathrm{CAR}_{1, t}\right)$ for the 36 months after the offering date for 143 Shipping IPOs. Twenty nine of the 36 monthly average adjusted returns are negative, with only 5 of them having t-statistics lower than -2.00 . After 36 months of secondary market trading the CAR is $-35.00 \%$ which is smaller in magnitude than the $-29.13 \%$ for the U.S reported figure by Ritter (1991). Given that the long term CARs are negative skewed a standard t-test overestimates the performance of IPOs. We again use skewness adjusted t-statistics combined with the bootstrap procedure proposed by Lyon et. al.[46]. The analysis show that the underperformance of IPOs is more pronounced once measured with CARs as compared to BHARs. 


\section{Table 5. Cumulative Abnormal returns (CAR) for Global Shipping Initial Public Offerings, 1984-2007}

Post listing long run average adjusted returns $\left(\mathrm{AR}_{t}\right)$ with associated t statistics and cumulative average returns $\left(\mathrm{CAR}_{t}\right)$ for the 36 months (where month one represents the market index adjusted return from the last sale price on the day of listing to the end of that calendar month) after going public, excluding the initial return. Our final sample constitutes with, 143 Global Shipping initial public offers of ordinary equity made between January 1984 and December 2007 calculated on the basis of a buy and hold strategy initiated using an equal euro investment in each issue purchased at the offer price for the issue.

\begin{tabular}{|c|c|c|c|c|}
\hline Month & No of firms trading & $\mathrm{AR}_{\mathrm{t}}(\%)$ & $t$-stat & $\mathrm{CAR}_{\mathrm{t}}(\%)$ \\
\hline 1 & 143 & 1.756 & 1.621 & 1.756 \\
\hline 2 & 143 & 0.623 & 0.638 & 2.379 \\
\hline 3 & 143 & 0.128 & 0.117 & 2.507 \\
\hline 4 & 143 & -0.873 & -0.952 & 1.634 \\
\hline 5 & 143 & -1.146 & -1.217 & 0.488 \\
\hline 6 & 143 & -0.871 & -1.021 & -0.383 \\
\hline 7 & 143 & -0.650 & -0.732 & -1.033 \\
\hline 8 & 143 & -1.257 & -1.127 & -2.29 \\
\hline 9 & 142 & -1.922 & -1.835 & -4.212 \\
\hline 10 & 142 & -2.378 & -2.582 & -6.59 \\
\hline 11 & 142 & -1.673 & -1.512 & -8.263 \\
\hline 12 & 141 & -0.329 & -0.493 & -8.592 \\
\hline 13 & 141 & 0.264 & 0.288 & -8.328 \\
\hline 14 & 140 & 0.491 & 0.564 & -7.837 \\
\hline 15 & 140 & -2.234 & -2.502 & -10.071 \\
\hline 16 & 139 & -1.816 & -1.723 & -11.887 \\
\hline 17 & 138 & -1.672 & -1.821 & -13.516 \\
\hline 18 & 138 & -1.228 & -1.309 & -14.744 \\
\hline 19 & 137 & -0.736 & -0.756 & -15.48 \\
\hline 20 & 137 & -1.629 & -1.692 & -17.109 \\
\hline 21 & 137 & -1.101 & -1.081 & -18.21 \\
\hline 22 & 135 & -0.422 & -0.439 & -18.632 \\
\hline 23 & 135 & 0.237 & 0.194 & -18.395 \\
\hline 24 & 134 & 0.713 & 0.673 & -17.682 \\
\hline 25 & 133 & -0.910 & -1.064 & -18.592 \\
\hline 26 & 133 & -1.397 & -1.452 & -19.989 \\
\hline 27 & 133 & -1.539 & -1.623 & -21.528 \\
\hline 28 & 133 & -0.932 & -0.981 & -22.46 \\
\hline 29 & 132 & -0.276 & -0.334 & -22.736 \\
\hline 30 & 132 & -1.420 & -1.253 & -24.156 \\
\hline 31 & 131 & -1.681 & -1.773 & -25.837 \\
\hline 32 & 130 & -2.529 & -2.703 & -28.366 \\
\hline 33 & 130 & -1.735 & -1.811 & -30.101 \\
\hline 34 & 130 & -1.058 & -1.05 & -31.159 \\
\hline 35 & 128 & -2.212 & -2.212 & -33.371 \\
\hline 36 & 127 & -1.634 & -1.926 & -35.005 \\
\hline
\end{tabular}




\section{Regression Results}

Ritter's (1991) constructed three benchmarks to measure the adjusted performance of the IPO firms: the size-matched, the B/M-matched, and the size-and-B/M-matched non-IPO portfolios. Since then size and book to-market characteristics have been documented extensively as important determinants of stock returns (Banz, [47]; Chan et al., [48]; Fama and French [49], Davis [50]; Lakonishok et al., [51]; Loughran and Ritter, [9]; Daniel and Titman, 1997; Davis et al., [52]; Daniel et. al. [53]. In our effort to investigate possible explanations for the long run underperformance of IPOs we run a series of multiple regression models, using the buy and hold abnormal returns (BHAR) and FF3F as dependent variables for one, two or three years after going public. The regression model is given as:

$\mathrm{BHAR}$ or $\mathrm{FF} 3 \mathrm{~F}=\mathrm{a}+\beta_{1} \log (1+\mathrm{AGE})+\beta_{2}(\mathrm{MRK})+\beta_{3}(\mathrm{UND})+\beta_{4} \log (\mathrm{SIZE})+\beta_{5}(\mathrm{H} / \mathrm{C})+\beta_{6}(\mathrm{EXC})+\varepsilon_{\mathrm{i}}$

Cross sectional regressions in short and post listing returns, initially using Buy and Hold Abnormal Return (BHAR) as dependent variable are reported in table 6. The results show that Age variable is statistically significant in the short run which lends fully support to the conclusion that smaller firms are subject to greater underpricing. A possible reason why our findings do strongly corroborate those found for U.S. IPOs is the similarities in the type of firms that enter the U.S. market. In the U.S., the average age of IPOs is approximately six years while the average age is closer to 50 years in Europe, Jenkinson and Ljungqvist [54]. We find that the average age of shipping companies raising money through initial public offerings, 31 years, is almost five times to that of the U.S.

Concentrating on the effects of age in the long term performance we observe that it is a significant factor in the three years period either if we study from the end of the first day of trading or from the end of the first month. The result clearly shows that firms with long history before they will go public perform better in the long term. This finding remain in line with U.S. evidence by Ritter (1991) indicating that operational experience is a signal for safe investment.

Second, we do not find any relation between market listing variable and underpricing. This result remain statistical insignificant once we look the returns in one, two and three years from the end of the first day of trading. Though, there is a light of significance when our study starts from the end of first month of trading and focus in one and three years return. The results in the last two cases contradicts as in the one year period it appears that Parallel/New Market Shipping IPOs perform better while in three years period the Main market IPOs yields better returns.

Although IPO underpricing is costly for the existing shareholders (issuers) it appears that a decision to move in a Shipping issue with non reputable underwriters can be catastrophic in terms of money left in the table. Our results clearly show that all Shipping firms listed with non reputable underwriters experienced severe level of underpricing. Thus, the main task for the underwriters and especially for the reputable which charge high fees are to acquire as many pieces of information as possible from the market, during the pre-selling period, before setting the issue price in order to attempt to reduce the level of underpricing. This structure challenges the underwriter to choose a mechanism that encourages truthful information disclosure instead of downplaying it to benefit from selling shares at the full information price in the after-market.

Further we summarize the findings for the effects of reputation of underwriters on the postissue performance of stocks. IPOs managed by more prestigious underwriters, significantly underperform IPOs conducted by less prestigious underwriters in long holding periods. This performance becomes transparent once the holding period starts from the end of first month of trading. It seems that an investment bank's reputation strongly impacts IPO aftermarket performance which is consistent with Carter et al. [40]. Opposite from this study Gajeski and 
Gresse (2006) show positive relation between the underwriters' reputation and the long-term performance of IPOs while they document that IPOs managed by good investment banks outperform compared to the performance of IPOs managed by investment banks that have a relatively poor reputation in the market.

The magnitude of returns by size do not provide any indication that smaller offers are subject to greater underpricing and so there is no supporting evidence for Ritter [55], Chalk and Peavy [56], Ritter [8] and Ibbotson et. al. [42]. The proceeds in USD generated from Shipping IPOs, indicates that the smaller the IPO, the greater the abnormal return of stocks up to two years following the IPO. Although overperformance seems to be stronger for the smaller firms in the 24 month long run period, it seems to disappear since the average abnormal returns of the small firms is statistical insignificantly over the 12-month and 36-month holding periods. In sum, our findings here parallel those related to firm size. A negative relationship between issue size and long-run performance is also inconsistent with Levis [57] and other studies of the US markets. Usually, issue size and company size are strongly correlated and so the larger negative returns of small size issues might be generated by their financially distressed position. Many small firms want to go public to raise a capital to finance their new investment projects and reduce their high level of debt. If the outcome of these projects ends up with success, this situation puts them in a more advantageous position, which eventually is reflected in share prices.

Fifth, a factor that proves to affect the newly listed firms' short term returns is the market condition (hot or cold) of the market during the period of a IPOs' operation. Consistent with expectations, our findings, displayed in Table 6, confirm the effect of market conditions on the underperformance puzzle of Shipping IPOs. We find that cold market Shipping IPOs, on their first six months in the market, significantly overperform the market and hot market IPOs continue to do so until the end of the 36-month holding period. There is a significant difference between the initial (first day) average abnormal returns of cold market and hot market IPOs (7.75\% vs. $26.71 \%$ ), respectively showing that owners of hot Shipping IPOs enjoy better short term returns.

The prices of hot market IPOs reverse in six months period as a result of change in beliefs of investors who realize too much optimism that is attributed to the new issues (overvaluation) under the hot market conditions after sometime following the IPO. This reversion in prices relative to the market generates overperformance of IPOs made on cold market. The cold market Shipping IPOs, which have lower initial returns due to weaker interest of investors than hot market Shipping IPOs, keep their outperformance for six months long-run period. IPOs in hot market might also be related with signalling hypothesis, which assumes that stock issue decision of companies is a signal given by the managers for the company shares that become overvalued. This statistical and economic significance of the results lead us to conclude that market conditions, whether hot or cold, significantly impact the post-Shipping IPO performance of stocks. Our results are also consistent with Ritter's (1991) observation that long-run IPO underperformance may be dominated by a few years in a sample, consistent with "windows of opportunity" for the firm.

The last factor we use to categorise our Shipping IPOs sample has been stock exchange classification. Surprisingly our results indicate that Shipping IPOs listed in the main Global Markets (NYSE, NASDAQ, LSE etc) experience high level of underpricing in the immediate aftermarket. Therefore, we expect the big number of investors associated with the major global markets will create the environment for high initial returns. Their role, based on our findings, appears to be crucial in the long term as main stock exchanges offer better long term returns in one, two and three years after listing. Thus, we are supportive of the Hahn and Ligon's (2004) 


\section{Table 6. Results of multiple regressions using BHAR}

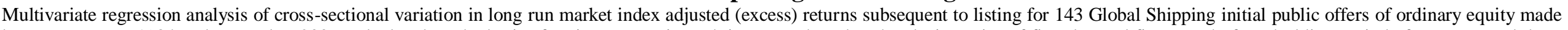

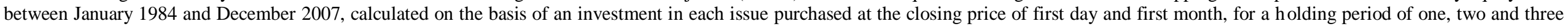

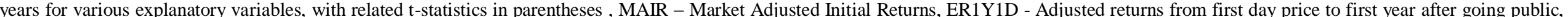

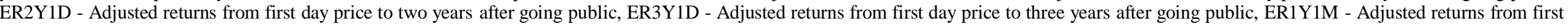

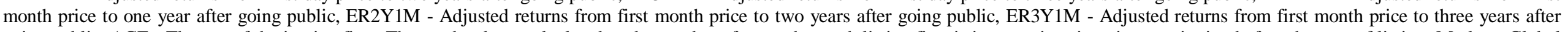

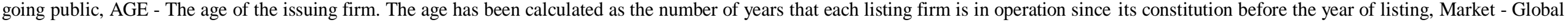

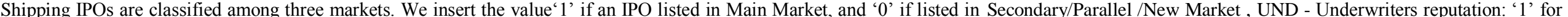

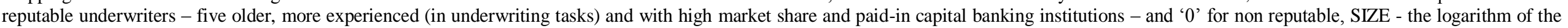

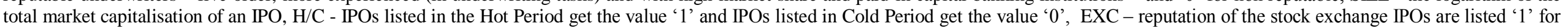

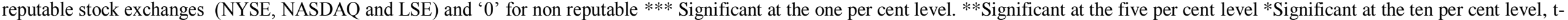
statistics are robust for heteroskedasticity using the Newey-West HAC Standard Errors \& Covariance process

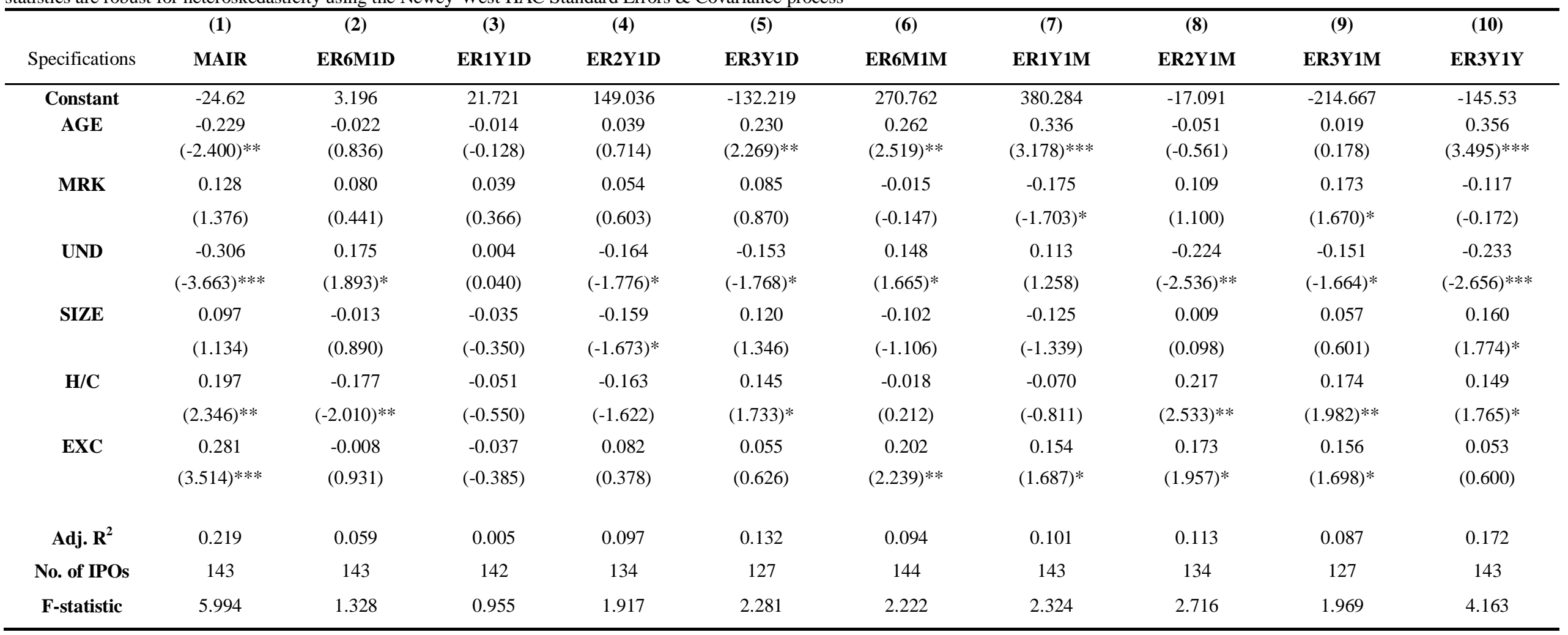




\section{Table 7. Results of multiple regressions using FF3F abnormal returns}

Multivariate regression analysis of cross-sectional variation in long run for the Fama and French (FF) three factor model $R_{p t}-R_{f t}=\alpha_{i}+\beta_{i}\left(R_{m t}{ }^{-}\right.$ $\left.\mathrm{R}_{\mathrm{ft}}\right)+\gamma_{\mathrm{i}} \mathrm{SMB}_{\mathrm{t}}+\delta_{\mathrm{i}} \mathrm{HML}_{\mathrm{t}}+\varepsilon_{\mathrm{pt}}$ subsequent to listing, 143 Global Shipping initial public offers of ordinary equity made between January 1984 and December 2007 calculated on the basis of an investment in each issue purchased at the closing price of first day and first month, for a holding period of one, two and three years for various explanatory variables, with related t-statistics in parentheses, MAIR - Market Adjusted Initial Returns, ER1Y1D - Adjusted returns from first day price to first year after going public, ER2Y1D - Adjusted returns from first day price to two years after going public, ER3Y1D - Adjusted returns from first day price to three years after going public, ER1Y1M Adjusted returns from first month price to one year after going public, ER2Y1M - Adjusted returns from first month price to two years after going public, ER3Y1M - Adjusted returns from first month price to three years after going public, AGE - The age of the issuing firm. The age has been calculated as the number of years that each listing firm is in operation since its constitution before the year of listing, Market Global Shipping IPOs are classified among three markets. We insert the value' 1 ' if an IPO listed in Main Market, and ' 0 ' if listed in Secondary/Parallel /New Market, UND - Underwriters reputation: ' 1 ' for reputable underwriters - five older and more experienced in underwriting tasks banking institutions - and ' 0 ' for non reputable, SIZE - the logarithm of the total market capitalisation of an IPO, H/C IPOs listed in the Hot Period get the value ' 1 ' and IPOs listed in Cold Period get the value '0', EXC - reputation of the stock exchange IPOs are listed ' 1 ' for reputable stock exchanges (NYSE, NASDAQ and LSE) and ' 0 ' for non reputable *** Significant at the one per cent level. **Significant at the five per cent level *Significant at the ten per cent level, t-statistics are robust for heteroskedasticity using the Newey-West HAC Standard Errors \& Covariance process

(1) (2)

(3)

(4)

(5)

(6)

\begin{tabular}{ccccccc} 
Specifications & ER1Y1D & ER2Y1D & ER3Y1D & ER1Y1M & ER2Y1M & ER3Y1M \\
\hline Constant & 23.749 & 112.969 & 174.860 & -28.758 & -13.496 & 95.251 \\
AGE & -0.018 & 0.124 & 0.211 & 0.248 & -0.033 & 0.015 \\
& $(-0.205)$ & $(1.689)^{*}$ & $(2.203)^{* *}$ & $(2.547)^{* * *}$ & $(-0.395)$ & $(0.112)$ \\
MRK & 0.058 & -0.058 & 0.102 & -0.177 & 0.125 & 0.187 \\
& $(0.616)$ & $(-0.895)$ & $(1.021)$ & $(-1.793)^{*}$ & $(1.320)$ & $(1.814)^{*}$ \\
UND & 0.003 & -0.045 & -0.179 & 0.099 & -0.216 & -0.164 \\
& $(0.037)$ & $(-0.754)$ & $(-1.921)^{* *}$ & $(1.047)$ & $(-2.416)^{* *}$ & $(-1.723)^{*}$ \\
SIZE & -0.026 & 0.088 & 0.133 & -0.147 & 0.013 & 0.078 \\
& $(-0.280)$ & $(1.311)$ & $(1.416)$ & $(-1.536)$ & $(0.132)$ & $(0.881)$ \\
H/C & -0.721 & -0.131 & 0.161 & -0.058 & 0.212 & 0.163 \\
& $(-0.750)$ & $(-1.775)^{*}$ & $(1.813)^{*}$ & $(-0.671)$ & $(2.316)^{* *}$ & $(1.852)^{* *}$ \\
EXC & -0.052 & -0.081 & 0.041 & 0.171 & 0.148 & 0.152 \\
& $(-0.565)$ & $(-1.212)$ & $(0.446)$ & $(1.827)^{*}$ & $(1.612)$ & $(1.611)$ \\
Adj. R $^{2}$ & 0.012 & 0.091 & 0.147 & 0.113 & 0.124 & 0.071 \\
No. of IPOs & 143 & 134 & 127 & 143 & 134 & 127 \\
F-statistic & 1.228 & 1.854 & 2.341 & 2.694 & 2.776 & 1.685 \\
\hline
\end{tabular}

notion that initial public offering underpricing boosts the subsequent secondary market liquidity (and long term returns) of the stock.

Turning to table 7, where the returns are measured by Fama and French three factors model, there is an interesting change in the results. We do not find any factors associated significant with any level of underpricing in the short term. In the long term field 'old' firms continue to offer better returns in a period up to one year and less reputable underwriters constitute a signal for good returns in two and three years period. Hot market condition remains a significant variable which indicates positive returns in two and three year's time while listing in a Major stock exchange can be an indication for satisfactory returns in one year period. Overall our findings give support to Krigman et al. [58] that first-day winners continue to be winners over the first year, and first day losers continue to be loser for the same period. 


\section{Conclusion}

This study provides unique evidence in the international literature by examining the performance of Global Shipping IPOs and scrutinizing the factors that might be effective on their performance. Specifically, using a sample of 143 IPOs launched on the Various Stock Exchanges over the 1984-2007 period, this study documents an average adjusted first day return of $17.69 \%$. The results of the study reveal that Global Shipping IPOs continue to outperform on a number of relevant benchmarks (BHAR and CAR), in the 12 and 24 months holding period following their listing in the market. On average, the Shipping IPOs were underperforming their market benchmark by $-9.91 \%,-4.40 \%$ and $-15.72 \%$, after one, two and three years of listing correspondingly. These rates of returns are considered very interesting, as they are consistent with those reported by Ritter (1991).

Shipping companies which entered the market during the hot period are seen to experience more underpricing of their share issues than the companies listed during the cold period. In the context of avoiding leaving a lot of 'money on the table', shipping companies may have to be more careful once they list during the hot periods in order minimize potential stock market underpricing. Furthermore, young shipping companies exhibit higher underpricing than those shipping offering with long operation history. This is related to information signalling to market participants, implying a kind of 'private' valuation by shipowners into the age of the firm before going public. Risk averse shipowners would improve expected utility by holding a diversified portfolio and not only a large stake in their own firm. Since this is not the case in companies with short history, it may signal that these shipowners are based on an implicit 'fair' firm value. In this case, shipowners of old companies would prefer to forego diversification benefits but avoid selling undervalued stocks. As investors realize shipowners' positioning, they would be keen to invest on shipping stocks of companies where owners are retaining larger holdings.

In order to detect the long-run performance phenomenon IPOs were classified under different characteristics, as discussed in the methodology section, and their significance was examined. Results show positive relationship between IPOs launched in the market after long operation history and their long run returns and negative relationship between firms launched in the stock market with reputable underwriters and their returns in the long term. Findings show positive relationship between IPOs listed in hot market period and their future returns. Listing in one of the major stock exchanges in the world is a positive signal for investors to participate in new shipping listings and significantly affects their returns in a three-year period. Surprisingly, there is no evidence for Shipping IPOs seeking listing in the primary/parallel markets. Overall, the results of the multivariate regressions concerning the long-run IPO performance revealed five statistically significant variables.

Offerings of Shipping IPOs appear to follow a "boom or bust" cyclical pattern in recent decades, not only in the U.S., but also in all countries. In "hot" markets, issuers all "want to get through the window at the same time." In "cold" markets, on the other hand, it is sometimes difficult for issuers to sell stock at any reasonable price. The last fully support the timing hypothesis i.e. managers of Shipping firms choose a window of opportunity to launch shipping IPOs. Initially those managers prefer to take their firms public when they have performed well earlier, and probably the IPO date is conditional on the firm's cycle of activity and operational performance.

To understand the Shipping IPO market in depth, further study should be implemented, focusing on the allocation of shares to institutional and individual investors. It would be interested to search the allocation mechanisms which are divided into three categories: fixedprice offerings, auctions and book-building. By definition, book-building procedures are 
handled solely by investment banks. Auction and fixed-price mechanisms can either be managed by underwriters or provided by exchanges. It would great to explore the problems that markets faces in this crucial area and suggest solutions which can improve the whole operation of Shipping IPOs.

The question that remains is how Shipping IPOs case differentiates from other studies of the area and provides comparatively low underpricing in the short term and low underperformance in the long-term to its investors. The explanation to this puzzle and support to our findings is given by the theory of 'flipping activity'. The theory suggests that there should be periods when investors are particularly confident about shipping firms' future projects and profits, and that managers are induced to make offerings of shipping IPOs in these periods. This finding is consistent with Krigman's et al. view (1999) that active buy and sell trades in the aftermarket during the first day of trading, is a good indication of future stock price performance. Therefore, the long-term low underperformance is a correction for this excess of optimism.

\section{References}

1. Syriopoulos, T., Financing Greek shipping modern instruments methods and markets. Research in Transportation Economics, 2007. 21: p. 171-291.

2. Allen, F. and G. Faulhaber, Signaling by underpricing in the IPO market. Journal of Financial Economics, 1989. 23(2): p. 303-323.

3. Grinblatt, M. and C. Hwang, Signaling and the price of new issue. Journal of Finance, 1989. 44(2): p. 47-58.

4. Welch, I., Seasoned offerings, limitations costs and the underpricing of initial public offerings. Journal of Finance, 1989. 44(2): p. 421-449.

5. Chemmanur, T., The pricing of initial public offers: A Dynamic model with information production. Journal of Finance, 1993. 48: p. 285-304.

6. Chahine, S., Underpricing Versus Gross Spreads: New Evidence on the Effects of Sold Shares at the Time of IPOs,. Journal of Multinational Financial Management, 2008. 18: p. 180-196.

7. Grammenos, C. and S. Marcoulis, A cross-section analysis of stock returns: The case of shipping firms. Maritime Policy \& Management, 1996. 23: p. 67-80.

8. Ritter, J., The long performance of Initial Public Offerings. Journal of Finance, 1991. 46(1): p. 3-28.

9. Loughran, T. and J. Ritter, The new issues puzzle. Journal of Finance, 1995. 50(1): p. 23-51.

10. Lee, P., S.L. Taylor, and T.S. Walter, Australian IPO pricing in the short and long-run. Journal of Banking \& Finance, 1996. 20(7): p. 1189-1210.

11. Cai, J. and K. Wei, The investment and operating performance of Japanese initial public offerings. Pacific-Basin Finance Journal, 1997. 5(4): p. 389-417.

12. Brounen, D. and P. Eichholtz, Initial Public Offerings: Evidence from the British, French and Swedish property share markets. Journal of Real Estate Finance \& Economics, 2002. 24: p. 103.

13. Jaskiewicz, P., et al., Long-Run IPO performance analysis of German and Spanish familyowned businesses. Family Business Review, 2005. 18(3).

14. Goergen, M., L. Renneboog, and A. Khurshed, Explaining the diversity in shareholder lockup agreements. Journal of Financial Intermediation, 2006. 15(2): p. 254-280.

15. Gajewski, J.F. and C. Gresse, A Survey of the European IPO Market. ECMI Paper, 2006.

16. Fama, E. and K. French, Multifactor explanations of asset pricing anomalies. Journal of Finance, 1996a. 51: p. 55-84.

17. Ritter, J., Why Has IPO Underpricing Changed Over Time? Unpublished working paper, University of Florida., 2002.

18. Ljungqvist, A., IPO underpricing, in Handbook of Empirical Corporate Financ, B. Eckbo, Editor. 2005, North-Holland. 
19. Loughran, T., J. Ritter, and K. Rydqvist, Initial public offerings: International insights. Pacific-Basin Finance Journal, 2008. 2(2-3): p. 165-199.

20. Ritter, J. and I. Welch, A review of IPO activity, pricing, and allocations. The Journal of Finance, 2002. 57: p. 1795-1828.

21. Champers, D. and E. Dimson, IPO Underpricing over the Very Long Run. Journal of Finance, forthcoming, 2009.

22. Chan, K., J. Wang, and K.C.J. Wei, Underpricing and long-term performance of IPOs in China. Journal of Corporate Finance, 2004. 10(3): p. 409-430.

23. Jakobsen, J. and O. Sorensen, Decomposing and testing Long-Run returns - with an application to Initial Public Offerings in Denmark. Working paper from Copenhagen Business School, Department of Finance, 2001.

24. Arosio, R., G. Guidici, and S. Paleari, What drives the initial market performance of Italian IPOs? An empirical investigation on underpricing and price support. Working Paper, University of Bergamo, 2000.

25. Keloharju, M., The winner's curse, legal liability, and the long-run price performance of initial public offerings in Finland. Journal of Financial Economics, 1993. 34(2): p. 251277.

26. Stehle, R., O. Ehrhardt, and R. Przyborowsky, Long-run stock performance of German initial public offerings and seasoned equity issues. European Financial Management, 2000. 6: p. 173-196.

27. Thomadakis, S., C. Nounis, and D. Gounopoulos, The Long Term Performance of Initial Public Offerings in the Athens Stock Exchange (1994-2002). working paper, 2008.

28. Aggarwal, R. and P. Rivoli, Evaluating the costs of raising capital through an initial public offering. Journal of Business Venturing, 1990. 6(5): p. 351-361.

29. McGroarty, R., Waves of demand, in Lloyd's Shipping Economist. 2006a. p. 7-10.

30. Derrien, F. and A. Kecskes, The Initial Public Offerings of Listed Firms. Journal of Finance, 2007. 62: p. 447-479.

31. Stokes, P., Ship finance: Credit expansion and the boom-bust cycle, L. Publications, Editor. 1997: London.

32. Brav, A., C. Geczy, and P. Gompers, Is the abnormal return following equity issuances anomalous? Journal of Financial Economics, 2000. 56(2): p. 209-249.

33. Drobetz, W., M. Kammerman, and U. Walchli, Long-run performance of initial public offerings: The evidence for Switzerland. Schmalenbach Business Review, 2005. 57: p. $253-275$.

34. Alvarez, S. and V. Gonzalez, Long run performance of initial public offerings (IPOs) in the Spanish capital market. Journal of Business Finance and Accounting, 2005. 32(1): p. 325-350.

35. Barber, B. and J. Lyon, Detecting long-run abnormal stock returns: The empirical power and specification of test statistics. Journal of Financial Economics, 1997. 43: p. 341-372.

36. Brav, A. and P. Gompers, Myth or reality? The long run underperformance of Initial Public Offerings: Evidence from Venture and Non Venture Capital Backed Companies. Journal of Finance, 1997. 32(5): p. 1791-1821.

37. Baron, D., A model of the demand for investment banking advising and distribution services for new issues. Journal of Finance, 1982. 37: p. 955-976.

38. Rock, K., Why new issues are underpriced. Journal of Financial Economics, 1986. 15(12): p. 187-212.

39. Ruud, J., Underwriter price support and the IPO underpricing puzzle. Journal of Financial Economics, 1993. 34(2): p. 135-151.

40. Carter, B., F. Dark, and R. Singh, Underwriter reputation, initial returns, and the long run performance of IPO stocks. Journal of Finance, 1998. 53(1): p. 285-311.

41. Chalk, A. and J. Peavy, Initial Public Offerings: Daily returns, offerings types and the price effect. Financial Analysis Journal, 1987. 65-69.

42. Ibbotson, R., J. Sindelar, and J. Ritter, The Market's problem with the pricing of Initial Public Offerings in Denmark. Journal of Applied Corporate Finance, 1994. 7: p. 66-74. 
43. Lowry, L., Why does volume fluctuate so much? Journal of Financial Economics, 2003. 67: p. 3-40.

44. Ritter, T. and H. Gemunden, The impact of a company's business strategy on its technological competence, network competence and innovation success. Journal of Business Research, 2005.

45. Buttimer, R., D. Hyland, and A. Sanders, REIT's, IPO waves and long run performance Real Estate Economics, 2005. 33(1): p. 51-87.

46. Lyon, J., B. Barber, and C. Tsai, Improved Methods for tests of Long-run abnormal stock returns. Journal of Finance, 1999. 54: p. 165-201.

47. Banz, R., The relationship between return and market value of common stocks. Journal of Financial Economics, 1981. 9(1): p. 3-18.

48. Chan, L., Y. Hamao, and J. Lakonishok, Fundamentals and stock returns in Japan. Journal of Finance, 1991. 37: p. 389-417.

49. Fama, E. and K. French, The cross section of expected stock returns. Journal of Finance, 1992. 47: p. 427-465.

50. Davis, J., The cross-section of realized stock returns: the pre-COMPUSTAT evidence. Journal of Finance, 1994. 50: p. 1579-1593.

51. Lakonishok, J., A. Shleifer, and R. Vishny, Contrarian investment, extrapolation, and risk. Journal of Finance, 1994. 49(1541-1578).

52. Davis, J., E. Fama, and K. French, Characteristics, covariances, and average returns: 1929-1997. Journal of Finance, 2000. 55: p. 389-406.

53. Daniel, K., S. Titman, and K.C. Wei, Explaining the cross-section of stock returns in Japan: factors or characteristics? Journal of Finance, 2001. 56: p. 743-766.

54. Jenkinson, T. and C. Mayer, Contracts and Competition. Oxford Review of Economic Policy, 1996. 12(4): p. 1-10.

55. Ritter, J., The hot issue market of 1980. The Journal of Business, 1984. 57(2): p. 215240.

56. Peavy, J., Returns on the initial public offerings of closed end funds. Review of Financial Studies, 1990. 3: p. 695-708.

57. Levis, M., The long-run performance of IPOs: The UK experience 1980-1988. Financial Management, 1993. 22: p. 28-41.

58. Krigman, L., W. Shaw, and K. Womack, The persistence of IPO mispricing and the predictive power of flipping. Journal of Finance, 1999. 54(3): p. 1015-1044. 
APPENDIX A: Leading Global Shipping IPOs by Market Capitalization

\begin{tabular}{llc}
\hline Company & Country of Listing & Market Cap (USD billion) \\
\hline A.P. Moller & Denmark & 32.67 \\
MISC & Malaysia & 7.67 \\
MOL & Japan & 7.04 \\
NYK & Japan & 7.03 \\
Bollore & France & 5.39 \\
Teekay & US & 3.05 \\
Cosco & China & 3.03 \\
'K' Line & Japan & 2.99 \\
Frontline & Norway & 2.84 \\
Hyundai MM & South Korea & 2.53 \\
OSG & US & 2.34 \\
OOIL & Hong Kong & 2.22 \\
Evergreen & Taiwan & 1.89 \\
Kirby & US & 1.85 \\
Bergesen Gas & Norway & 1.77 \\
Hanjin & South Korea & 1.67 \\
China Shipping & China & 1.61 \\
Torm & Denmark & 1.60 \\
NOL & Singapore & 1.60 \\
W. Wilhelmsen & Norway & 1.58 \\
Safe Bulker & US & 1.03 \\
\hline
\end{tabular}

APPENDIX B: Stock Price of Selected Shipping Companies since IPO in the U.S.

\begin{tabular}{|c|c|c|c|c|c|}
\hline Company & IPO Date & Market & $\begin{array}{c}\text { IPO Price } \\
(\$)\end{array}$ & $\begin{array}{l}\text { First Day } \\
\text { Close (\$) }\end{array}$ & $\begin{array}{l}\text { Price }(\$) \\
10 / 10 / 08\end{array}$ \\
\hline Top Ships & 23 Jul'04 & NASDAQ & 11.00 & 10.60 & 3.00 \\
\hline Dry Ships & 3 Feb '05 & NASDAQ & 18.00 & 20.20 & 19.09 \\
\hline Diana & 18 Mar '05 & NYSE & 17.00 & 17.30 & 14.54 \\
\hline Teekay LNG & 5 May ‘05 & NYSE & 22.00 & 24.30 & 11.38 \\
\hline Aries Maritime & 3 Jun '05 & NASDAQ & 12.50 & 12.97 & 1.26 \\
\hline Eagle Bulk & 23 Jun'05 & NASDAQ & 14.00 & 13.50 & 7.49 \\
\hline TBS Intern. & 24 June '05 & NASDAQ & 10.00 & 10.05 & 8.01 \\
\hline Quintana & $15 \mathrm{Jul}$ `05 & NASDAQ & 11.50 & 11.26 & 7.04 \\
\hline Genco & 22 Jul ‘05 & NASDAQ & 21.00 & 20.87 & 17.96 \\
\hline Seaspan & 9 Aug '05 & NYSE & 21.00 & 19.42 & 12.77 \\
\hline Horizon & 27 Sep ‘05 & NYSE & 10.00 & 10.75 & 5.00 \\
\hline Excel & 15 Sep '05 & NYSE & 21.00 & 15.95 & \\
\hline ACL & 7 Oct '05 & NASDAQ & 21.00 & 28.30 & 6.12 \\
\hline StealthGas & 6 Oct '05 & NASDAQ & 14.50 & 13.70 & 6.89 \\
\hline Double Hull & 13 Oct '05 & NYSE & 12.00 & 12.05 & 3.98 \\
\hline Omega Navig. & 7 Apr ‘06 & NASDAQ & 17.00 & 16.00 & 6.83 \\
\hline Danaos & 6 Oct '06 & NYSE & 21.00 & 20.85 & 9.32 \\
\hline Ultrapetrol & 13 Oct '06 & NASDAQ & 11.00 & 10.54 & 3.81 \\
\hline Aegean Marine & 8 Dec '06 & NYSE & 14.00 & 15.00 & 11.37 \\
\hline TEEKAY Offsh. & 14 Dec '06 & NYSE & 21.00 & 25.00 & 8.20 \\
\hline Capital Product & 30 Mar '07 & NASDAQ & 21.50 & 26.75 & 7.75 \\
\hline Oceanfreigh Inc & $25 \mathrm{Apr}{ }^{\prime} 07$ & NASDAQ & 19.00 & 19.31 & 7.37 \\
\hline Paragon Ship. & 10 Aug '07 & NASDAQ & 16.00 & 14.50 & 5.50 \\
\hline OSG America L.P & 9 Nov ‘07 & NYSE & 19.00 & 18.75 & 6.45 \\
\hline Navios Maritime & 13 Nov '07 & NYSE & 20.00 & 19.25 & 5.06 \\
\hline TEEKAY Tankers & 13 Dec '07 & NYSE & 19.50 & 20.01 & 9.70 \\
\hline Safe Bulkers & 29 May ‘08 & NYSE & 19.00 & 18.90 & 7.00 \\
\hline
\end{tabular}


